\title{
ТЕХНIЧНI НАУКИ
}

DOI: https://doi.org/10.32839/2304-5809/2020-9-85-23

УДК 637.5.072

Іваніщева О.А., Пахомська О.В.

Вінницький торговельно-економічний інститут Київського національного торговельно-економічного університету

\section{ОСОБЛИВОСТІ ВПРОВАДЖЕННЯ СИСТЕМИ НАССР НА М'ЯСОПЕРЕРОБНИХ ПІДПРИЄМСТВАХ УКРАЇНИ}

Анотація. У статті досліджено методологічні основи впровадження НАССР як системи управління якістю та безпечністю на підприемствах м'ясної промисловості. Предметом дослідження є ключові принципи НАССР, переваги ціеї системи, сучасний стан та перспективи розвитку в Україні. Проаналізовано актуальні проблеми впровадження системи НАССР на підприємствах м'ясопереробної галузі, можливості їх вирішення на сьогоднішній день. Визначено особливості процесу проведення аналізу небезпечних чинників (небезпек) на стадіях ідентифікації та аналізу небезпечних чинників. Уточнено користь від впровадження системи НАССР для виробників м'ясопереробної галузі та переваги від впровадження системи НАССР для держави. Окреслено роль навчання працівників м'ясопереробного підприемства і ознайомлення 3 цією системою споживачів як найважливіших аспектів ефективного впровадження НАССР.

Ключові слова: НАССР, система, м'ясо, небезпечні чинники, критичні точки контролю, виробничий процес, якість, безпечність.

Ivanishcheva Olga, Pakhomska Olena

Vinnytsia Institute of Trade and Economics of the Kyiv National University of Trade and Economics

\section{PECULIARITIES OF HACCP SYSTEM IMPLEMENTATION AT MEAT PROCESSING ENTERPRISES OF UKRAINE}

Summary. The problem of food safety and quality is now acute around the world. It is a priority for governments, food producers, industry, trade and consumers. As practice shows, in the process of implementation of the HACCP system at meat processing enterprises of Ukraine there are constantly a number of objective and subjective obstacles that require detailed analysis and suggestions for possible ways to overcome them. The methodological bases of HACCP implementation as a quality and safety management system at the meat industry enterprises are investigated in the article. The subject of the research is the key principles of HACCP, the advantages of this system, the current state and prospects of development in Ukraine. The current problems of HACCP system implementation at the enterprises of the meat processing industry and the possibilities of its solution to date have been analyzed. The peculiarities of the process of conducting the analysis of dangerous factors (dangers) at the stages of identification and analysis of dangerous factors are determined. The benefits of implementing the HACCP system for meat producers and the benefits of implementing the HACCP system for the state are clarified. The role of training employees of the meat processing enterprise and acquaintance with this system of consumers as the most important aspects of effective implementation of HACCP is outlined. As the issue of quality of meat and meat products, which occupy a significant share in the diet of the population of Ukraine, is particularly important and priority, the analysis of the current state of implementation of the HACCP system, existing problems in meat processing enterprises, possible solutions are an urgent task that requires a comprehensive study. Potentially dangerous factors of biological, chemical and physical nature at each stage of technological process of production of meat products, their reasons and factors of distribution are analyzed.

Keywords: HACCP, system, meat, hazards, critical control points, production process, quality, safety. Постановка проблеми. Проблема безсьогоднішній день гостро відчувається в усьому світі. Вона є пріоритетною для урядів, виробників харчових продуктів, представників промисловості, торгівлі та споживачів.

Сьогодні перед підприемствами м'ясної промисловості України стоять нові завдання, зокрема, освоєння нових ринків збуту своєї продукції. Потенційні зарубіжні партнери все частіше ставлять перед українськими виробниками харчових продуктів вимоги щодо існування на підприемстві діючої системи управління безпечністю харчових продуктів на основі принципів HACCP.
Оскільки питання якості м'яса та м'ясних продуктів, які займають значну питому частку в раціоні населення України, є особливо важливим та пріоритетним, аналіз сучасного стану впровадження системи НАССР, існуючих проблем саме на підприемствах м'ясопереробної галузі, можливих шляхів їх вирішення є актуальним завданням, що потребує всебічного дослідження та вирішення.

Аналіз останніх досліджень і публікацій. Дослідженням питання якості та безпечності харчової продукції на основі впровадження системи НАCCP на підприемствах харчової галузі займалося багато зарубіжних та вітчизняних науковців. Серед них можна назвати таких вчених, як В. Пла- 
хотін, В. Андрійчук, Я. Жаліло, Й. Завадський, Л. Свчук, Д. Крисанов, П. Саблук, О. Піддубний, М. Портер, Б. Райзберг, В. Стівенсон, Р. Фатхутдінов, Д. Богатко, Т. Семко та ін. У працях даних науковців прослідковуеться глибокий аналіз суті системи управління безпечністю та якістю харчових продуктів, законодавчих основ для можливості впровадження системи НАССР в Україні, пропонуеться розробка конкретних елементів системи, плану НАССР для підприемств галузі, можливі шляхи його реалізації.

Виділення невирішених раніше частин загальної проблеми. Незважаючи на значні напрацювання 3 даної теми, окремі її аспекти потребують подальшого вивчення та обумовлюють доцільність проведення наукових пошуків 3 питань харчової безпеки. Як показуе практика, у процесі впровадження системи НАCСР на м'ясопереробних підприемствах України постійно виникає ряд об’ективних і суб'єктивних перешкод, що вимагають детального аналізу та пропозицій можливих шляхів їх подолання.

Мета статті. Головною метою статті є дослідження методичних основ впровадження системи НАССР як системи управління якістю на м'ясопереробних підприемствах України, аналіз актуальних проблем у цій сфрері та виявлення можливостей для її вирішення на сьогоднішній день.

Виклад основного матеріалу. Найважливішим завданням подальшого розвитку ринку м'ясних виробів е всебічне задоволення потреб споживачів в якісній продукції. Якість, як показник, е невід'ємною частиною продукту і займає особливе місце в харчовому ланцюзі «від поля до столу» у системі управління якістю та безпечністю харчових продуктів на основі НАССР.

Основними проблемами розвитку ринку м'ясної продукції в Україні на сучасному етапі e монополізація його окремими товаровиробниками у більшості регіонів країни; зниження обсягів промислового виробництва м'ясних виробів i зростання крафртових технологій; скорочення асортименту та зниження якості м'ясних виробів; ускладнення їх доставки у віддалені села та селища через відсутність транспортної і збутової інфраструктури; низька ефективність функціонування підприемств м'ясної галузі.

Аналіз літературних джерел свідчить, що безпека харчових продуктів - це відсутність токсичної, канцерогенної, мутагенної, алергенної та іншої несприятливої для організму людини дії харчових продуктів під час їх споживання в загальноприйнятих кількостях, межі яких установлюються Міністерством охорони здоров'я України [1].

На кожному етапі технологічного процесу виробництва м'ясних виробів є потенщійно можливі небезпечні чинники біологічної, хімічної та dpiзичної природи. В процесі підготовки сировини до виробництва можуть виникнути небезпеки, зумовлені біологічними та фізичними факторами: зараження сировини мікроорганізмами та потрапляння сторонніх домішок. Небезпеки виникають в результаті порушення режимів приймання, зберігання, а також із навколишнього середовища по винні персоналу.

Проаналізовано потенційно можливі небезпечні чинники біологічної, хімічної та фрізичної природи на кожному етапі технологічного процесу виробництва м'ясних виробів, їх причини та фрактори поширення є. В процесі підготовки сировини до виробництва можуть виникнути небезпеки, зумовлені біологічними та фізичними факторами: зараження сировини мікроорганізмами та потрапляння сторонніх домішок. Небезпеки виникають в результаті порушення режимів приймання, зберігання, а також із навколишнього середовища по винні персоналу.

3 метою підвищення конкурентоспроможності м'ясних виробів і зменшення їх цін необхідно впроваджувати принципи системи НАCCP (Hazard Analysis and Critical Control Points), що закріплено на законодавчому рівні Законом України № 2042-VIII «Про державний контроль за дотриманням законодавства про харчові продукти, корми, побічні продукти тваринного походження, здоров'я та благополуччя тварин» [2]. На даний час вона $е$ найбільш прийнятною формою системи управління якістю і забезпечення безпечної м'ясної продукції в Україні та закордоном, оскільки дае можливість ідентифікувати конкретні види небезпечних чинників і встановити заходи щодо їхнього контролювання для гарантування безпечності харчових продуктів. Вона використовуеться для забезпечення безпечності харчових продуктів протягом усього ланцюга виробництва і реалізації харчового продукту.

Система HACCP - це інструмент управління, який забезпечуе більш структурований та науковий підхід до контролю ідентифікованих небезпечних чинників, ніж підхід через традиційну інспекцію і процедури контролю якості.

Система НACCP використовуе визначення критичних точок в технологічному ланцюзі виготовлення м'ясних виробів для попередження проблем якості і безпеки. У ній ідентифікуються конкретні мікробіологічні, хімічні, фізичні ризики, встановлюються заходи контролю для гарантії безпечності. Система НАССР надае впевненості у ефективності організації управління безпечністю харчових продуктів на м'ясопереробному підприемстві. НАССР плануе зменшення потенційних ризиків для здоров'я споживачів запобігаючи, ідентифікуючи, коригуючи проблеми на всьому технологічному процесі від первинного виробництва до кінцевого процесу. Поряд з підвищенням безпечності харчових продуктів існують і інші вигоди від застосування системи. Вона підсилюе відповідальність та ступінь контролю, призводить до кращого розуміння та гарантування всіма учасниками харчового сектору безпечності м'яса та м'ясних виробів, тим самим даючи нову мотивацію в їхній роботі [2].

Система НАСCP трунтуеться на трьох основних принщипах. Першим принщипом системи $\varepsilon$ аналіз небезпечних чинників (небезпек). Сама назва НАССР передбачає, що аналіз небезпечних чинників е одним 3 найважливіших завдань. Неправильно проведений аналіз небезпечних чинників при виготовленні м'ясних виробів призведе до розроблення неадекватного плану НАСCP. Аналіз небезпечних чинників вимагае володіння грунтовними технічними та науковими знаннями в різних сферах для належної ідентифікації всіх потенційних небезпечних чинників. Процес проведення аналізу небезпечних чинників (небез- 
пек) включає дві стадії: ідентиорікацію небезпечних чинників та аналіз небезпечних чинників [3].

Визначення критичних точок контролю - другий принцип системи НАССР. Настанова Комісіі Кодекс Аліментаріус визначає критичну точку контролю (КТК) як «етап, на якому контроль можливий i суттевий для запобігання чи усунення небезпечних чинників для харчових продуктів, або їхнього зменшення до прийнятного рівня» [4]. Точкою контролю може бути сировина, місце розташування м'ясопереробного підприемства та його приміщень, виробнича практика, процедури (методики), склад продукту або технологічний процес виробництва, де можуть застосовуватися заходи, щоб запобігти або мінімізувати вплив небезпечних чинників на безпечність м'ясних виробів. Слід зауважити, що застосовуваний тут термін «контроль» означає «знаходиться під контролем», і його не слід плутати 3 випробуванням, перевіркою або аудитом. Хоча застосування належної виробничої практики повинне гарантувати, що під час виготовлення безпечних харчових продуктів під контролем знаходиться багато точок, деякі важливі аспекти повинні бути проаналізовані з метою визначення, чи становлять вони КТК. Коли в деякій точці технологічного процесу виготовлення м'ясних виробів або на етапі його підготовлення існуе висока ймовірність появи потенційно безпечних чинників, потрібні специфрічні методи контролю.

Якщо будь-який небезпечний чинник було ідентифріковано на етапі, де для досягнення безпечності контроль є необхідним, і якщо жодного контрольного заходу не існуе на будь-якому іншому етапі, тоді продукт або процес повинні бути модифіковані на цьому, попередньому або наступному етапах для введення контрольного заходу. Небезпечними чинниками можна управляти (контролювати) багатьма способами. Мікроорганізми можуть знищуватися нагріванням, а їхне розмноження може запобігатися або обмежуватися низькими чи високими температурами, низькою вологістю, консервантами та ін. Ретельне відокремлення сировини або необроблених продуктів від оброблених буде запобігати або обмежувати перехресне забруднення. Візуальний огляд, застосування металевих детекторів, лабораторних приладів і т. ін. можуть бути едективними для контролювання фізичних небезпечних чинників [5].

Визначення критичних точок контролю можна спростити застосуванням «дерева прийняття рішень» або «дерева рішень». Прикладом такого «дерева рішень» $є$ дерево, що включено до документу Комісії Кодекс Аліментаріус «Система аналізу небезпечних чинників і критичні точки контролю (НАССР) і настанови щодо її застосування", яке зазначає підхід на основі логічного висновку. Застосування «дерева рішень» повинне бути гнучким і потребуе ясного розуму та врахування типів операцій (наприклад, виробництво, оброблення, зберігання, розподілення чи інше). Але воно може не підходити для всіх операцій 3 харчовими продуктами, а тому користуватися ним слід 3 урахуванням профресійних думок, а іноді його слід видозмінювати. Можуть використовуватися й інші підходи для визначення КТК, що базуються на аналізі ризиків.
Повідомлення про ризик - третій та кінцевий елемент аналізу ризику. Кодекс Аліментаріус стисло визначає поняття повідомлення про ризик: «інтерактивний процес обміну інформацією та думками стосовно ризику серед фрахівців з оцінення ризику, з управління ризиком та інших зацікавлених сторін». Інше ширше визначення дає Національна Академія наук США: «інтерактивний процес обміну індормацією та думками серед окремих осіб, груп та установ... (який) передбачає численні повідомлення про характер ризику та інші повідомлення, безпосередньо не зв’язані з ризиком, які виказують стурбованість, думки чи реагування на повідомлення про ризик або на законодавчі та інституційні положення щодо управління ризиком» [5].

Повідомлення результатів оцінки ризику та управління ризиком використовують для багатьох цілей. Якість та безпечність м'ясних виробів залежить від відповідального ставлення всіх залучених осіб на всіх стадіях в харчовому ланцюзі, включаючи споживачів. Споживачі вимагають доступу до адекватної інформації про потенційні небезпеки та відповідні застережні заходи, які мають вживатися під час остаточного приготування та споживання м'ясних виробів. Крім того, споживачі вимагають ознайомлення та розуміння заходів контролю за безпечністю м'ясних виробів, які впроваджує уряд в інтересах охорони здоров'я споживачів.

Користь від впровадження системи НАССР для виробників м'ясопереробної галузі беззаперечна: виробництво білыш безпечної продукції, що знижуе діловий ризик і підвищуе задоволеність споживача; стабільна репутація і захист торговельної марки; узгодженість із законодавством; персонал має чіткіше уявлення щодо вимог до безпечності виготовлених виробів та методів їх виконання; демонструє зобов'язання підприємства щодо безпечності продукції; краща організація персоналу та використання робочого часу; ефективність витрат, зменшення збитків у перспективі; менша ймовірність одержати скарги від споживачів та їхня довіра; можливість збільшити доступ на ринки збуту.

Переваги від впровадження системи НАССР для держави: полегшення інспекцій та ефрективніший контроль м'ясної галузі; поліпшення охорони здоров'я та зменшення витрат на охорону здоров'я; полегшення міжнародної торгівлі [6].

Незважаючи на всі вище зазначені переваги впровадження i функціонування системи НАCCP, на сьогоднішній день у м'ясопереробній галузі є чимало проблем, що перешкоджають iii впровадженню. На підприемствах відсутні зобов'язання з боку керівництва, недостатня підготовка кадрів, недолік коштів, не розуміння принципів НАССР, недоліки процедур по оцінці ризиків. Тому впровадження системи вимагає додаткових матеріальних витрат, які керівництво не завжди сприймає, вважає зайвими [7].

Шляхами вирішення цих проблем може повинно стати переобладнання процедур забезпечення якості або належної виробничої практики, вже встановлених на м'ясопереробному підприемстві, перегляду цих процедур як частини системного підходу та їхнього належного інтегрування у виробничий процес, що і передбачає впровадження НАССР. 
Навчання працівників м'ясопереробного підприемства, ознайомлення 3 цією системою споживачів $е$ найважливішими аспектами ефективного впровадження НАCCР. Як допомога в організації спеціального навчання, що сприяе виконанню плану НАССР, мають бути розроблені робочі інструкції і методики, які встановлюють завдання для виробничого персоналу. Ці документи повинні бути в кожній критичній точці контролю [6].

Працівники підприемств м'ясної промисловості повинні мати більш високий рівень професійної підготовки з питань якості, тому що їм доведеться брати участь у всьому комплексі робіт 3 оцінювання потреб споживачів, дослідження кон'юнктури ринку, стратегічного планування компанії, розроблення нової продукції, контролю якості проектів, оцінювання ступеня підготовки виробництва і осмислення інших завдань, які вирішуються функціональними службами підприемства. Зростае особиста відповідальність кожного за виконання роботи на кожній конкретній ділянці. У виробництві повинні використовуватись інноваційні технології, більш складне устаткування, контрольно-вимірювальні засоби, що призведе до зростання значення статистичних методів контролю, автоматизованого проектування нової продукції [8].

Висновки 3 даного дослідження і перспективи. В статті висвітлено особливості впровадження системи НАССР на м'ясопереробних підприемствах України, аналіз існуючих проблем та шляхів ïx вирішення, адже саме НACCP дає можливість систематично забезпечувати високу якість і безпечність м'ясної продукції, виводити ії на міжнародні ринки. Це - актуальна модель управління якістю та безпечністю харчових продуктів. При застосуванні принщипів НАССР значною мірою знижуються рівні ризиків виникнення небезпек для життя і здоров'я споживачів м'ясної продукції.

Перспектива подальших досліджень передбачається у дослідженні можливих шляхів впровадження принципів НАССР у вітчизняну м'ясопереробну промисловість у контексті сучасних тенденцій, забезпечення високої гігієни м'яса та м'ясних виробів, створення сприятливих умов для виходу українських продуктів на ринки інших країн світу.

\section{Список літератури:}

1. Траченко Л.А. Блок-схема управління якістю на підприемствах харчової промисловості. Науковий журнал "Вісник». Тернопіль : «Економічна думка» ТНЕУ, 2007. № 1. С. 79-86.

2. Про державний контроль за дотриманням законодавства про харчові продукти, корми, побічні продукти тваринного походження, здоров'я та благополуччя тварин. URL: https://zakon.rada.gov.ua/laws/show/204219 (дата звернення: 15.04.2019).

3. Система аналізу ризиків і критичних контрольних точок XАCCП. URL: http://www.milkiland.nl/upload/pdf/ laws/ua/Instruktsiya_HACCP.pdf (дата звернення: 20.04.2019).

4. Комісія Кодекс Аліментаріус. Принципи і керівні вказівки по проведенню оцінки мікробіологічного ризику. $\mathrm{CAC} / \mathrm{GL}, 1999.30 \mathrm{c}$.

5. Крутяк Н.Р. Система НАССР. Довідник. Львів, 2003. С. 218.

6. Белов Ю.П. Розробка та впровадження системи управління безпечністю харчових продуктів НАССР. Світ якості України. Київ, 2005. № 2. С. 42-45.

7. Семко Т.В., Іваніщева О.А. Вимоги ЄС щодо безпечності харчових продуктів та особливості впровадження систем НАССР у м'ясній промисловості України. Продовольчі ресурси. Збірник наукових праць. № 11 . Київ : ТОВ «Видавництво «БАРМИ», 2018. С. 155-164.

8. Богатко Д.Л., Богатко Н.М. Особливості запровадження системи НАССР на м'ясопереробних підприемствах України. Проблеми зооінженерії та ветеринарної медицини.2014. № 28(2). С. 49-55.

\section{References:}

1. Trachenko, L.A. (2007). Blok-skhema upravlinnya yakistyu na pidpryyemstvakh kharchovoyi promyslovosti [Block diagram of quality management in the food industry]. Naukovyy zhurnal "Visnyk». Ternopil': «Ekonomichna dumka» TNEU, vol. 1, pp. 79-86.

2. Pro derzhavnyy kontrol' za dotrymannyam zakonodavstva pro kharchovi produkty, kormy, pobichni produkty tvarynnoho pokhodzhennya, zdorov'ya ta blahopoluchchya tvaryn [About the state control over observance of the legislation on foodstuff, forages, by-products of an animal origin, health and well-being of animals]. URL: https://zakon.rada.gov.ua/laws/show/2042-19 (accessed: 15.04.2019).

3. Systema analizu ryzykiv i krytychnykh kontrol'nykh tochok HACCP [HACCP risk analysis system and critical control points] URL: http://www.milkiland.nl/upload/pdf/laws/ua/Instruktsiya_HACCP.pdf (accessed: 20.04.2019).

4. Krutyak, N.R. (2003). Systema HACCP. Dovidnyk [HACCP system. Directory]. L'viv, p. 218.

5. Komisiya Kodeks Alimentarius. Pryntsypy i kerivni vkazivky po provedennyu otsinky mikrobiolohichnoho ryzyku [Codex Alimentarius Commission. Principles and guidelines for microbiological risk assessment]. SAS/GL, 1999. 30 p.

6. Belov, Yu.P. (2005). Rozrobka ta vprovadzhennya systemy upravlinnya bezpechnistyu kharchovykh produktiv HACCP [Development and implementation of the HACCP food safety management system]. Svit yakosti Ukrayiny. Kyiv, no. 2, pp. 42-45.

7. Semko, T.V., \& Ivanishcheva, O.A. (2018). Vymohy YES shchodo bezpechnosti kharchovykh produktiv ta osoblyvosti vprovadzhennya system HACCP u m"yasniy promyslovosti Ukrayiny [EU requirements for food safety and peculiarities of introduction of HACCP systems in the meat industry of Ukraine]. Prodovol'chi resursy. Zbirnyk naukovykh prats'. № 11. Kyiv: TOV «Vydavnytstvo «BARMY», pp. 155-164.

8. Bohatko, D.L., \& Bohatko, N.M. (2014). Osoblyvosti zaprovadzhennya systemy HACCP na m"yasopererobnykh pidpryyemstvakh Ukrayiny [Features of HACCP system introduction at meat processing enterprises of Ukraine]. Problemy zooinzheneriyi ta veterynarnoyi medytsyny, no. 28(2), pp. 49-55. 